\title{
Rural tourism as a factor of sustainable development: a case study of Sukur World Heritage Site in Adamawa State, Northeastern Nigeria
}

\author{
W. Nzeda Tagowa \\ Department of Political Science and Public Administration, \\ Adamawa State University, Nigeria
}

\begin{abstract}
Tourism as one of the world's fastest growing industries has the potential to enhance sustainable development by its propensity to promote accelerated growth, income increase, improved transportation and conservation of ecosystems, among other variables. Tourism attractions abound in Africa and Nigeria has more than fair share of tourism potentials. Most tourism attractions in Nigeria are located in the rural areas. Rural tourism can therefore be utilized as a tool for sustainable development. This paper reviews the development of tourism in Nigeria in general and specifically undertakes a case study of Sukur World Heritage Site in Adamawa State, Northeastern Nigeria, as an example of rural tourism for sustainable development. The paper highlights Sukur development plan and advances strategies for utilization of the site for sustainable development. Such strategies surround the central objective of community participation and environmental protection and preservation, while taking cognizance of the risks involved in the development of a tourism site of the like of Sukur Cultural Landscape.
\end{abstract}

Keywords: rural tourism, landscape, sustainable development, cultural tourism, community participation, pro-poor management.

\section{Introduction}

The universally accepted meaning of tourism is that it involves a "network of activities of persons who travel and stay in destinations outside their homes and 
work places for a while, and of those who provide them with goods and services during their sojourns," [1]. The purpose of a tourist's journey is a factor which has given rise to a lot of activities such as religious tourism, spots tourism, health tourism, cultural tourism, eco-tourism, conference tourism, shopping tourism, etc. Tourism is therefore, an economic activity that centres on production, from attraction of the very crude traditional based artisans' workshops to state of the art factory attractions. Most of Nigeria's famous tourism attractions are centres of economic activities, many of which are supported by the country's tourism policy which professes to promote "tourism-based rural enterprises and accelerated rural-urban integration and cultural exchanges" [2].

Unlike in the case of other industries such as agriculture and manufacturing where products are delivered to the consumer, the consumer in the tourist industry must travel to the point of production (tourist destination) in order to consume the product. This makes tourism multi-sectoral and hence creates linkages between the tourism industry and other sectors of the economy. Thus the local and international entrepreneurs are therefore connected directly or indirectly to tourism.

Tourism is one of the fastest growing industries in the world with a high propensity for local and international revenue generation to support economic development. It is projected that by the middle of the $21^{\text {st }}$ century, revenue generation from tourism will surpass that of oil. In spite of its potentials, tourism remains undeveloped in Nigeria, yet the country is aptly described as the "ultimate tourism destination in Africa" [3]. This is not only because the country wields a significant influence and comparative advantage on the continent but also because her tourism potentials are second to none in Africa.

Nigeria is the tenth largest country in the world with an area of about 932,960 square kilometres and a population of over 140 million people of diverse culture and abundant physical and environmental resources of tourism significance. These attractions range from hills, waterfalls, springs, lakes, mountains and caves found across the length and breadth of the country. There are a mixture of man-made and natural attractions comprising flora and fauna. Many of the wildlife in Nigeria are protected as national parks, game reserves, sanctuaries, wetland and zoological gardens.

\section{Tourism development in Nigeria}

Tourism development is still in its evolutionary stage in Nigeria and its growth reflects the growing importance of tourism to the national economy. Tourism consciousness began with the formation of the Nigerian Tourism Association (NTA) in 1962. The activities of the association led to the admission of Nigeria as a member of the International Union of Official Travel Organization (IOUTO) in 1964. Ten years later, a report of the African Development Bank (ADB) indicated that Nigeria possessed enormous potentials for the development of the tourism sector. That was why the Murtala Obasanjo regime replaced the NTA with the Nigeria Tourism Board (NTB) under Decree No.54 of 1976. The Board was empowered to make policies that will: (i) encourage people living in Nigeria 
to take their holidays therein and people from abroad to visit Nigeria; (ii) encourage the provision and improvement of tourism amenities and facilities; (iii) provide advisory information services on tourism in Nigeria; (iv) promote and undertake researches in the field of tourism; and (v) grade and classify hotels in such a manner as may be prescribed [4]. The NTB however failed to make a meaningful impact to the country's tourism industry. To strengthen tourism in Nigeria, Decree No.54 of 1976 was repealed with Decree No.81 of 1992 to give birth to the Nigeria Tourism Development Corporation (NTDC). The NTDC is currently the apex tourism agency of the Federal Government of Nigeria in charge of the promotion, marketing and coordination of tourism activities in Nigeria.

The Federal Ministry of Tourism, Culture and National Orientation and the NTDC assume full responsibility for initiation, monitoring and maintenance of links with the states on tourism matters. The ministry is also responsible for policy research, planning and formulation, monitoring and funding of nationally oriented tourism infrastructure and represents the country in international tourism organizations. There is also the National Council on Culture and Tourism (NCCT) which ensures the coordination of national planning and development of tourism in the entire federation. Whenever tourism sites are identified and declared national monuments, the National Commission for Museums and Monuments (NCMM), established under Decree No. 77 of 1979 will be involved in the management and protection of such sites. There are also the state ministries responsible for tourism in all the states of the federation. The state ministries implement the directives of the Federal Ministry of Tourism, Culture and National Orientation, initiates projects and control land allocation in line with the federal government policy. Below the state ministries are the state tourism boards and the local tourism committees at the local government levels.

\section{Rural tourism attractions in Adamawa State, Northeastern Nigeria}

The Adamawa State of Nigeria was the product of the split of the then Gongola State of Northeastern Nigeria into two to give birth to Adamawa and Taraba States. Adamawa State is the second largest state in Nigeria with an area of 42,158 square kilometres and located between latitudes $7^{\circ} 28$ to $10^{\circ} 56 \mathrm{~N}$ and $11^{\circ} 30$ to $13^{\circ} 75 \mathrm{E}$. The state has a projected population of about 3.5 million. This population is made of a multiple ethnic groups that are mainly Bantu speaking people that live in segmented large and small communities that speak different languages and dialects.

The state is basically a mountainous area mostly traversed by the Upper Benue River and its tributaries. It has a tropical climate marked by dry and rainy seasons: the rainy season begins in April and ends in October while the dry season begins in November and ends in March. The temperature in the state varies from place to place with a minimum average of $15.2^{\circ} \mathrm{C}$ and maximum average of $43^{\circ} \mathrm{C}$. December and January are the coldest while March and April are the hottest. 
The major occupation of the people is agriculture and the entire state can be described as a rural state as people practice generally peasantry agriculture. The location of the state in the Sudan and Guinea Savannah belts between Cameroun/Mandara mountain ranges and its diverse cultural landscape provides the state with potentials for rural tourism. Tourism awareness just began in Adamawa State with the establishment of the State Tourism Board in 1999.

\subsection{Tourism attractions in the Adamawa State, Nigeria}

Two types of tourism attractions can be identified in the state - the natural and the cultural. The natural tourist attractions include the Gashaka Gumti Natural Park at Toungo Local Government Area (LGA), the Bwasu Hot Spring in Lamurde LGA, the Kamale peak and the Sukur kingdom at Madagali LGA, the Kiri Dam at Shelleng LGA and the Three-sister rocks at Song in Song LGA. The cultural tourist attractions comprise the cultural diversities of the state which are expressed in various cultural festivities such the Vunon (Farai) wrestling festival at Demsa, Yinagu and Njuwa fishing festivals, various dances by diverse communities, etc. In fact, up to 32 cultural festivals take place in the state in a year. There are several other cultural attractions such as the ancient tombs of historical significance like Modibbo Adama tomb at Gurin Fufore LGA. One of the most important tourist attractions of Adamawa State is the Sukur Kingdom in Madagali LGA which is the main subject of this study. The Sukur people retain their cultural values and the superiority of their ancient works and this endeared the kingdom to get international recognition when UNESCO enlisted it as the $25^{\text {th }}$ World Heritage Site in 1999.This is one of the several sites enlisted by UNESCO in Africa and the first of its kind in Nigeria.

The term "heritage" broadly refers to the natural and the cultural environment such as knowledge and living experiences, landscapes, continuing cultural practices, historic places and built environments, biodiversity and collections. Heritage thus records and expresses the long process of historic development, forming the essence of diverse national indigenous and local identities and an integral part of modern life. It is also a dynamic reference point and positive instrument for growth and change and a particular heritage and collective memory of a locality or community is an irreplaceable and an important foundation for sustainable development [5].

A world heritage site is a globally significant site that is considered and designated as having an outstanding universal value and recognized by the United Nations Educational, Scientific and Cultural Organization (UNESCO) as having global importance to be conserved by a country under the United Nations Convention Concerning the Protection of the World Natural and Cultural Heritage of 1972 [6]. The Convention provides for international cooperation in the protection and conservation of cultural and natural heritage such as monuments, group of buildings, works of man or combined work of man and nature, natural features, natural sites, geological and physiographical formations [6]. Specific sites of significance and value such as forests, lakes, mountains, deserts building complexes or cities, that have been found to be of outstanding universal value from the point of view of history, art or science, aesthetics 
ethnological or anthropological, conservation and natural beauty and therefore confirmed and included in the list of sites maintained by the International World Heritage Programme, are considered as heritage sites by UNESCO [6].

There are several hundreds of these sites all over the world and 122 of them are in Africa, 25 out of the 122 are in West Africa [7]. Two of these sites are the Sukur Cultural Landscape and the Osun-Osogbo Sacred Grove in Nigeria. These sites are not only intrinsically valuable as heritage sites but can serve the purpose of development, especially for rural communities, if properly developed into tourist havens.

\section{Sukur World Heritage Site}

Sukur people belong to the inhabitants of the Mandara Mountains referred to by ethnographers as montegnards, a French word for hill dwellers that live mainly through terrace farming [8]. Sukur is located on the Mandara Highlands between Nigeria and Cameroon at a distance of about $270 \mathrm{~km}$ from Yola, the Adamawa State capital in Northeastern Nigeria. Sukur depicts an ancient hilltop settlement with a rich history of iron technology, flourishing trade and strong political and cultural traditions that survived external influences that is associated with the meeting of cultures that transformed most African societies. Sukur people still retain their traditional settlement on the mountain at about 2,000 to 3,000 feet above sea level on the Magger Valley in an area of $31 \mathrm{~km}^{2}$ some $25 \mathrm{~km}$ West of Mokolo in Cameroon and $17 \mathrm{~km}$ South East of Madagali. It is bounded in the East by the Republic of Cameroon and in the North by Tur and in the East by M'idu and in the West and South by the Kingdom of Dzu-yel, respectively [9]. This community had developed a complex society and chiefdom in the precolonial period that evolved a hierarchical political system that is described as a 'divine kingdom' and historians have noted that the power of Sukur is inscribed on the landscape in the form of substantial building projects such as paved ways, construction of ceremonial areas, walled enclosures terraced fields and other features [3].

Sukur oral history indicates that the people migrated from M'Chikili area of Mokolo District of the Republic of Cameroon to settle on the Sukur Plateau. Their present population is about two to three thousand people. Their major occupation is subsistence farming, iron smelting and blacksmithing. The community consists of 27 clans that settle along such lineages even though a number of them have relocated to other places in Madagali local government area. It is difficult to ascertain the exact age of Sukur civilization in their present location but archaeological findings have established that the precincts of Sukur had been inhabited in their present place for well over 800 years from the artefacts dugged in the area [10].

The Sukur cultural landscape consists of the Sukur Plateau and its scenic cultural features. These include the Hidi Palace, the stone architectural designs, the shrines, the paved walkways and the iron smelting furnaces, traditional graveyards, agricultural terracing and threshing floors. The Hidi Sukur's palace (King's Palace) is situated at the centre of Sukur town, about sixteen times the 
size of a normal Sukur house and surrounded by a stone wall of about eight to nine feet high. The palace has four gates and each gate is used for special purposes. Stone paved walkways lead to Sukur from the north to the east and this can be found along the hillsides leading to the top of the hill. This was designed to minimise erosion and to facilitate easy climbing and horse riding. This relates to the domesticated landscape for terrace farming as terraces are constructed up the hills to stabilise the soil and provide series of stepped level benches adoptable to hill farmers.

Due to the presence of iron-rich formations in the Mandara Mountains, a vibrant iron smelting culture has developed among the Sukur people. There is a greater density of slag and other debris in the Sukur area than anywhere on the Mandara Mountain and this breeds iron smelting [9]. Sukur furnaces require at least three men to bellow and the smelting teams vary in line with changes in the domestic cycle as well as the pattern of the neighbourhood cluster. There is a spectacular mammoth baobab tree which the Sukur culture forbids anybody from touching. This tree can be compared to the Nji Ngla, a mysterious tree in Iware Ila, in Osun State in Western Nigeria which when cut splashes blood [9]. The Sukur culture and tradition believe that whoever touches the tree will become a hermaphrodite, exhibiting both male and female genital characteristics.

\subsection{Legal status of Sukur World Heritage Site}

The Mandara Archaeological Project of Nicholas David of 1984 exposed the immense historical and cultural potentials of Sukur and its cultural landscape leading to the preparation of the dossier that made it possible for its inscription as a UNESCO World Heritage Site in 1999. Prior to 1999 efforts were made by the Adamawa State Government to establish a legal status for the site within the laws of the Federal Republic of Nigeria. Thus in 1997, the Adamawa State Government sought the approval of the Hidi-in-Council to declare Sukur Cultural Landscape a state monument. This was granted and the state government gave the site a legal status through the Adamawa State Gazette No. 47 Vol.7 of $20^{\text {th }}$ November, 1997. This is in line with the provisions of Decree No. 77 of 1979 which empowers the NCMM to protect and preserve all such monuments in Nigeria as cultural heritage [11]. This made it possible for the state government to liaise with the NCMM to prepare grounds for enlistment of Sukur on the World Heritage list. It also provides opportunity for the community, the local government, the state government and the NCMM to cooperate and develop an agenda for management of Sukur cultural landscape. The inscription of the site as a World Heritage Site in 1999 further enhances the imperative for not only managing and conserving the site for posterity, education and research purposes, protection and creation of national identity and awareness, but also for tourism and sustainable development purposes [12]. 


\subsection{Sukur cultural heritage conservation, development and management plan}

Conservation of heritage and management of heritage sites and monuments in Nigeria is the responsibility of the NCMM in collaboration with other stakeholders of the respective areas. The Adamawa State Government set up its agency for museums and monuments which carried out some restoration works at the Hidi's palace in 2004. The staffs of the state Council of Arts and Culture have been engaged in archaeological research in the area with a view to reenacting the process of iron smelting to reinvent the traditional furnaces found in the area. The NCMM has also produced some tourism flyers, posters, postcards guidebooks and brochures to advertise its tourism attraction. It has also created a website for Sukur cultural landscape. Above all, a Conservation, Development and Management Master Plan had been adopted for implementation.

Two layers of management structure have been adopted: the traditional and modern systems of management. The traditional management system involves the granting of traditional management rights to the Sukur community through the Hidi and his Council of title holders. Thirteen clans are involved with each can having responsibility in communal efforts and maintenance Sukur culture. Sukur community is a purely communal one. Community works are carried out through family units, neighbourhoods, homesteads and clans. Special communal maintenance works are carried out through general communal mobilization of all ages. Through this method traditional technical knowledge is transmitted to the younger generations. The imperative for the preservation of Sukur cultural landscape is the strong adherence to the cultural norms and values, believes in taboos that set limits to certain behaviours as well as sacrosanct observance of rituals and non-encroachments of sacred areas.

The modern management system is based on a management plan that is adopted in 1999. The plan allocated responsibilities to various stakeholders including the Sukur community, the NCMM, the Adamawa State Government, and the UNDP. In addition to the role of traditional management of Sukur community, Sukur community is again represented in the modern management structure through Sukur Development Association (SDA), and the Sukur Monument Support Group (SMSG). Both groups have the task of construction of rest places along the ascending routes, provision of heritage trails, clearing of bushes, planting of trees and organization of festivals.

The NCMM, through its Directorate of Monuments, is responsible for faithful implementation of the guidelines for preservation, conservation and management of Sukur site in accordance with the World Heritage Convention. It has a Curator stationed at Yola who serves as the Site Manager. He coordinates stake holder cooperation and the activities of the site guides, site archaeologists and ethnographers who carry out reconnaissance surveys in accordance with the management objectives of achieving sustainable development. The Commission is to cooperate with the state government and other stakeholders to improve the quality of agricultural production in the site and help to improve the quality of life of Sukur community. 
The UNDP is another stakeholder in the Sukur site project. Under the Sukur management system the UNDP also undertakes to assist in capacity building and participatory development system of the community, implement a comprehensive package that would upgrade Sukur Cultural Landscape to a viable instrument for sustainable development of the Sukur community. The UNDP has identified key priority development needs of Sukur people based on the following broad objectives [12]: (i) increase awareness of prevailing health problems of the community; (ii) increase of farmers' access to improved seeds and seedlings for increased agricultural productivity and reduction of postharvest lost; (iii) increase access to safe drinking water; (iv) increase the rate of adult literacy; (v) increase access to productive assets for establishment of cottage industries; and (vi) provision of opportunities for skill acquisition that is relevant to the needs of the community.

\section{Tourism development of Sukur cultural landscape}

One of the objectives of management system is therefore to develop and actualise the tourism potential of the site. Stakeholders are to cooperate in the development of infrastructure such as roads, electricity and other social amenities. Already a seventeen kilometre grade B road has been constructed to the foot of the hill and a 200kva generating plant has been dropped there. There is a primary school and a health clinic on the hill. Presently, a private investor has developed an eight-bedroom chalets at the foot of the hill and an eighteen bedroom chalet of the first phase of 60-bedroom of the Three-star Country Side Resort under the Sukur World Heritage Site Master Plan is still under construction. A website has been created on Sukur and tourists and researchers have been showing more and more interests on the site. However, the sorry sight is the plight of the people around the landscape and especially those on top of Sukur Plateau and the need for sustainable development of the people.

A visit to Sukur Kingdom will reveal that existing efforts have little result for the hill dwellers. Early researchers have revealed that the montagnards on the Mandara Mountain have developed a kind of agroforestry that sustained high population densities even in the face of raids and other threats to the surrounding plains. Their continued sustainability was simply the montagnard way of life which is unfortunately associated with extreme poverty of people living on incomes of less than One Dollar a day [13].

Unfortunately the management activities on Sukur have been carried on adhoc basis since 1999. The Federal Government of Nigeria formally constituted Sukur World Heritage Site Conservation, Preservation and Management Committee only recently on January $12^{\text {th }}, 2010$. The Committee is responsible for coordinating all activities of development of the site to world class tourism standards including management, conservation and preservation of the site. An important part of management of a tourism site is conservation and preservation. Preservation entails all measures carried out to preserve the physical remains of sites and their historical settings. It involves all preventive measures designed to safeguard the originality, integrity and associated features of tangible and 
intangible values of the heritage site. These cover the regulatory measures, customary laws and practices as well as the scientific measures taken to preserve the site [14].

The NCMM also provides site representation and interpretation through the resident guides, archaeologists and the Curator as Site Manager. The commission has built an interpretation centre where Sukur Cultural artefacts are displayed to aid site interpretation for visitors. It has also displayed directional informational signs at various locations on the visitor trail to aid visitor understanding and appreciation of the landscape.

There is concern for the promotion of cultural awareness and identity of the Sukur people. The cultural calendar of the Sukur people is being monitored and promoted through government assistance in the organization of Sukur cultural festivals such as Yawel, Zoaka and Buk. These festivals now attract more people to the top of the hill. Recently the Minister of Tourism, Culture and National Orientation declared that the Yawel festival of Sukur would be organized as a national event as from 2010 [15].

\subsection{Challenges of tourism development of Sukur cultural landscape}

The enlistment of Sukur as a World Heritage Site poses a serious developmental challenge considering the rural and remote nature of the site. Since 1999 there has been a very slow pace of development at the site. As an international heritage site, the area requires infrastructural facilities and social amenities that meet basic international standards. The slow pace of development can be linked to the long time it took the government to put a management committee in place and inadequate financial resources to develop the site. There is generally poor road network in the northeastern part of Nigeria, unstable flight schedules poor communication network and lack of adequate accommodation within Sukur vicinity. There is also acute shortage of drinking water, medical and other recreational facilities. Moreover, the community development efforts in Sukur Kingdom is skewed in favour of the downhill dwellers thereby generating mixed feelings among the hill dwellers who feel marginalized. As contact with modernity increases, the problem of traditional prohibitions on the landscape, difficult terrain, distance to the site and threats to the landscape by bush fires and overgrazing are serious challenges that need to be addressed if sustainable tourism is to be achieved. This is because tourism for sustainable development requires a management that will generate income and conserve the site for future generations. To satisfy the cultural tourist requires a plan of action that provides quality service that can sustain the interest of the traveller. These are challenges that Sukur World Heritage Site Management Committee must face squarely.

\section{Strategies for management of Sukur forsustainable development}

The preceding discussion has so far revealed that Sukur cultural landscape has a remarkable socio-cultural capital that can be mobilized to advance, cultural and 
eco-tourism tourism in Northeastern Nigeria. Its element of natural environment makes it fascinating for local, national and international tourism development. Even more fascinating is fact that Sukur people have survived the difficulty of weather, hostile raids and unequal relations with the world around them [13].

There is no doubt that such excruciating objective conditions of the people have led to the collapse of their economy. This happened around the 1960s, leaving the relics of their cultural landscape and terrace fields for subsistence agriculture and hence one of the poorest communities in Nigeria [16]. This poverty can be glaringly seen on the Sukur Plateau. A "pro-poor" approach to eco-cultural tourism as earlier suggested by Sterner and David can still be adopted for application if the life ways of the montagnard experience are to be safeguarded in their contact with modern life [13]. This requires grass root involvement with specific educational and functional goals needed for sustainable development.

Pro-poor tourism according to its proponents generates net benefits for the poor in the sense that it does not only takes care of social and environmental factors but also forms part of "sustainable eco-tourism and community-based tourism" that is "fair," "just" and "equitable" [13]. The latter three terms are preferred here because they are the bane of policy implementation in Nigeria. Two major objective of pro-poor approach are participation and holistic livelihood strategies.

\subsection{Community participation and holistic livelihood strategies}

On the one hand the poor people must participate in their tourism decisions and on the other hand their livelihood must be reflected in the way tourism development activities are controlled. This should centre on mobilization and education to address issues sensitive the community. There is a feeling that "the montagnard communities have suffered a long history of exploitation and are sensibly skeptical of proposals from beyond their hill" [14]. According to Adeleke [17], participation encourages awareness of national and cultural resources of the country and at the same time enables the country to be proactive in promoting what it sees unique in terms of developing appropriate tourism strategy for an area. If management is to achieve sustainable development it must be sensitive to the issue of natural resources, the community and the tourists. Already, there are speculations that the extensive works of archaeologists in the area have economic undertones even though such intentions have not been documented. This position holds that there are large deposits of gold, iron and other valuable minerals that attract archaeologists like David Nicholas, for example [14]. That is why Butler in Adeleke [17] argued that one of the purposes of tourism development is to avoid confrontation between tourists and community residents with a reasonable chance of being involved in the industry. The idea of community participation has thus become a tool for conservation and tourism development which has been increasingly recognized by government, business and community. Community participation has more advantage in promoting biodiversity conservation, responsible tourism and enhancing sustainable development of the local communities 
The holistic livelihood strategy recognizes the livelihood concern of the poor in terms of economic, social and environmental needs in the short and long terms. Sukur museum was established by Sukur Development Association. The association might have been influenced by town and city dwellers but it operates on the wishes of those living in Sukur. Opinions actually converge on acceptable tourism strategies that bother on respect for and protection of traditional ways and sacred sites. These practices must be supported and promoted if sustainable development is to be achieved.

The pro-poor approach therefore has the potential to encourage the hill dwellers to continue to live on top of the hills rather than relocating to the plains, towns and cities. Relocation can be slowed down with the provision of more schools, health facilities and improvement of the well established terrace farming and sustainable traditional skills and knowledge. Although the Sukur Conservation, Preservation and Management Master Plan recognizes the traditional management system of the Sukur people, the representatives of Sukur community in the recently inaugurated Management Committee are town, city or plain dwellers except the Hidi Sukur himself. This makes the management system heavy-handed and top-down. This arrangement is more likely to overshadow the traditional management system and its bountiful objectives.

\subsection{Integration of traditional and modern management systems}

To plug the gap that may be created by the top-down approach, there is need to integrate the traditional and the modern methods of conservation and management. Therefore, integrating the relevant aspects of the indigenous and foreign technologies to address social, cultural, political and economic challenges of conservation and preservation is required. To ensure maximum benefits to the tourists and the visited alike, local people have to be involved in the strategic planning procedures. The goal of integration lies on the need to harness the potentials for sustainable development. Traditional practice alone cannot provide adequate protection for negative effects of development such as deforestation, wildlife depletion, bushfires, dilution of cultures, and disruption of social life which are glaringly noticeable in Sukur.

To curb such menaces, patrol guards should be employed to conduct joint patrols along with age-grade associations to prevent illegal activities and protect sacred places. Patrol guards along with age-grades may also cooperate with the Hidi to come up with new regulations to guide their mode of operations in line with traditional rules and regulations with due cognisance of taboos and sanctions. Age-grades that will participate in this guard duty must undergo training in conservation, preservation and area management techniques. Integrating traditional and modern management methods has promises of achieving sustainable tourism and development.

\subsection{Risk management strategy}

A risk management strategy should be employed in all dimensions. Risk is a potential damage that could arise as a result of the occurrence of a hazard with a 
given degree of certainty. Bevon Morison argues that "risk is different from hazard in the sense that hazard is a source of danger, while risk involves the likelihood of a hazard developing into some adverse occurrence that may cause loss, injury or some other form of damage" [18]. Many risks are associated with tourism especially in developing countries. Risks such as crimes, drug peddling, visitor harassment, erosion, pollution, deforestation, bushfires and deliberate damage to artefacts can affect profitability and viability of sustainable tourism and development.

The World Tourism Organization (WTO) indicates that tourists are shifting their tests from sun, sand and sea to special interests such as eco-tourism, health tourism and other types of tourism that allow them to interface more closely with the culture of the people of their destinations [18]. With improved infrastructure and good management, Sukur will enjoy an influx of tourists. In addition to the above mentioned risks, Sukur has additional man-made risks such as poverty, inadequate housing, education and medical care. As Sukur Cultural Landscape is being developed for sustainable tourism, risk management must be integrated into the management system. Policy makers must therefore understand the nature of risks and the cost implication for alternative remedial courses of action in order to represent them to the wider population at large. This requires risk assessment in terms of hazard determination and risk analysis and a comprehensive risk management system. Risk management involves actions required to qualify, mitigate and control risk. It must be noted that risk assessment and analysis unavoidably requires interaction between the scientists and policy makers because the policy maker requires scientific information to put the risk analysis in context [18].

\section{Summary and conclusion}

This paper has established that despite the potentials of the Sukur Cultural Landscape, the development of tourism facilities and infrastructure to meet the need of visitors has been slow. The stakeholders have adopted a conservation, preservation and management master plan, but the implementation of the plan had been carried on an ad-hoc basis and this slows the pace of tourism development of site. The master plan was designed within the context of the Nigerian National Tourism Development Master plan which requires synergy among the federal, state and local governments as well as institutions, communities and individuals to package Nigeria's tourism resources to the international community. Stakeholders in the Sukur Cultural Landscape project and their agencies are the Federal Government, Adamawa State Government, Madagali Local Government and the United Nations agencies like UNESCO and the UNDP. They have all shown interest to cooperate to develop the tourism potentials of the site for sustainable development. There are other private interests and individuals in the project.

Tourism is a global industry that needs international standards and best practices. The Sukur project requires the basic international standard to be able to attract tourists. But the sad side of the project is that the Sukur Community is 
one of the poorest in Nigeria and this poverty manifests in all strata of the community due to collapsed economy. Therefore, a pro-poor strategy of management which is built of community participation and holistic livelihood approach is here canvassed and recommended. This approach should be able to address social and environmental factors that is not only community based but a kind of tourism that is just, fair and equitable. The pro-poor approach should be matched with the integration of traditional and modern methods of management that will bridge the gaps between the two approaches by addressing the social, political, economic, cultural and environmental needs of conservation, preservation and management. This will put the community at the centre stage of management and sustainability.

Above all, a comprehensive risk management system should also be put in place. The greatest risk in this area is poverty and poverty can give birth to many things. There are other risks associated with tourism development such natural disasters and criminal activities. The risk management system should also be taken along side environmental impact of assessment though rigorous scientific analysis of hazardous conditions that would have negative impact on sustainability of Sukur cultural Landscape.

\section{References}

[1] Munzali A.D., "Tourism enriches - one village one product," an integrated community based tourism initiative," a paper presented on the occasion of the world tourism day celebration, Warri, Nigeria, p.1, September 27, 2006.

[2] Landi, H.J. "Strategies for promoting tourism in developing countries: the Nigerian case," a paper presented at the national conference on the development of Strategies for viable cultural promotion and tourist development in a reforming economy, Zaranda Hotel, Bauchi, Nigeria, pp. 2-3, March 15, 2005.

[3] NTDC, "Report of a study survey of Sukur as UINESCO World Heritage Site", pp. 2-3, Monday $13^{\text {th }}$ to Friday $17^{\text {th }}$ September, 1999.

[4] Nigeria, Federal Republic, Decree No.54 of 1976.

[5] Obereime, J. O. "Heritage conservation master plan for sustainable development in Nigeria," National commission for museums and monuments (NCMM), January, 2010.

[6] See Encarta World Dictionary [North American edition] \& (p) 2009, Microsoft Publishing Corporation, file:///C:Document o/o20 and o/o20 Settings/-/Desktop/Heritage o/o 20fi...and Wikipedia-the free Encyclopaedia, file:///c:/Documents and settings/-/Desktop/Heritage files/world heritage sites definition by Babylon's, accessed 26/02/2010.

[7] List of World Heritage Sites in Africa in Wikipedia-the free encyclopaedia,file://c:/Documents and settings/-/Desktop/list o/o 20o/ofo/o... accessed o5/03/2010

[8] "Mandara mountains homepage," file://Mandara Mountains Homepage.htm. 
[9] See Yawal Sukur 2010 Festival (Profile of events) and brief on Sukur World Heritage Site, p.9. p.9, 21-25 February, 2010,

[10] See David, N. "The ethnoarchaeological and field archaeology of grinding at Sukur, Adamawa State, Nigeria." African Archaeological Review, Vol. 15, No. 1, 1999 (13-53). The NTDC report supra [3 ] also indicated that David Nicholas' archaeological findings dating Sukur civilization to 800 years used Carbon $\mathrm{C} 14$ method of dating to determine the age of the artefacts dugged in the area.

[11] See Adamawa State Gazette No. 47, Vol. 7, 1997.

[12] See Sukur World Heritage Site conservation, development and management master plan, , p.1, January 2008.

[13] Sterner, J. and David, N. "A Mandara international peace park: a project for sustainable development and eco-cultural tourism in the Mandara Mountains of Northeast Nigeria and Northern Cameroon," 1985.

[14] Adeyenju, F. And Ologe, O.K., "Critical issues in implementing the Nigerian tourism master plan: the roleof federal, state and local government", paper presented at the inauguration of Sukur World Heritage Site conservation preservation and management master plan, $12^{\text {th }}$ January, 2010.

[15] Gada, J. B. "Speech delivered on the occasion of the inauguration of the management committee of Sukur World Heritage Site", January 12, 2010.

[16] David C. Woolman visited Sukur form Mubi in 1965 and reported that the Sukur economy "had collapsed by 1960" and that in spite of the "gains and much deserved recognition, the Mandara Mountains region remains one of the poorest parts of Nigeria". See Woolman, D.C., "Sukur revisited: recollections of cultural exploration in the Mandara Mountains", December, 1965.

[17] Adeleke, O. B. "Community participation in conservation: a pathway to tourism development in protected areas", Journal of research and national development, vol. 7 No.1, June 2009, p.2 and also Hiwasaki, S. "Objectives of community participation", in Chinese Sociology and Anthropology, vol. 1 No. 3, 2003, referred to in Adeleke.

[18] Morison, B. "Integrating risk assessment and management and disaster mitigation in tourism development planning in Jamaica", Borgese, E.M. (ed.), Ocean yearbook 17, University of Chicago, Chicago, p.295.2003 